\title{
Responses of the alga Pseudokirchneriella subcapitata to long-term exposure to metal stress
}

\author{
Manuela D. Machado ${ }^{\mathrm{a}, \mathrm{b}}$, Ana R. Lopes ${ }^{\mathrm{c}}$, Eduardo V. Soares ${ }^{\mathrm{a}, \mathrm{b}, *}$ \\ a Bioengineering Laboratory, Chemical Engineering Department, ISEP-School of Engineering of Polytechnic Institute of Porto, Porto, Portugal \\ ${ }^{\mathrm{b}}$ CEB-Centre of Biological Engineering, University of Minho, Braga, Portugal \\ ${ }^{c}$ LEPABE, Laboratory for Process Engineering, Environment, Biotechnology and Energy, Faculty of Engineering, University of Porto, Porto, Portugal
}

\section{H I G H L I G H T S}

- Heavy metals provoke a perturbation of the physiological status of Pseudokirchneriella subcapitata.

- $\mathrm{Cd}(\mathrm{II}), \mathrm{Cr}(\mathrm{VI})$ and $\mathrm{Cu}(\mathrm{II})$, at high concentrations, cause the loss of membrane integrity.

- $\mathrm{Cd}(\mathrm{II}), \mathrm{Cr}(\mathrm{VI}), \mathrm{Cu}(\mathrm{II})$ and $\mathrm{Zn}(\mathrm{II})$ inhibit esterase activity in a dose dependent manner.

- Heavy metals affect mitochondrial function and photosynthetic activity.

- Fluorescent probes are a useful tool in the identification of toxicity targets of the heavy metals.

\section{A R T I C L E I N F O}

\section{Article history:}

Received 30 July 2014

Received in revised form 7 March 2015

Accepted 8 April 2015

Available online 9 April 2015

\section{Keywords:}

Esterase activity

Heavy metals toxicity

Membrane integrity

Mitochondrial membrane potential

Photosynthetic activity

\section{G R A P H I C A L A B S T R A C T}

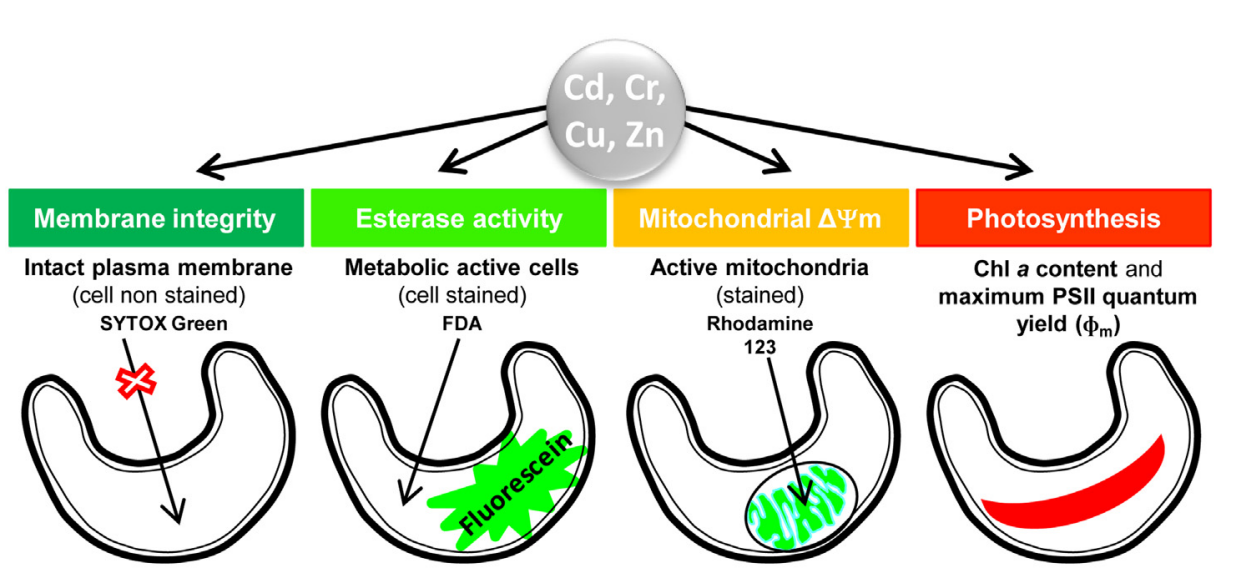

\begin{abstract}
A B S T R A C T
The green alga Pseudokirchneriella subcapitata has been widely used in ecological risk assessment, usually based on the impact of the toxicants in the alga growth. However, the physiological causes that lead algal growth inhibition are not completely understood. This work aimed to evaluate the biochemical and structural modifications in P. subcapitata after exposure, for $72 \mathrm{~h}$, to three nominal concentrations of $\mathrm{Cd}(\mathrm{II}), \mathrm{Cr}(\mathrm{VI}), \mathrm{Cu}(\mathrm{II})$ and $\mathrm{Zn}(\mathrm{II})$, corresponding approximately to $72 \mathrm{~h}-\mathrm{EC}_{10}$ and $72 \mathrm{~h}-\mathrm{EC}_{50}$ values and a high concentration (above $72 \mathrm{~h}-\mathrm{EC}_{90}$ values). The incubation of algal cells with the highest concentration of $\mathrm{Cd}(\mathrm{II}), \mathrm{Cr}(\mathrm{VI})$ or $\mathrm{Cu}(\mathrm{II})$ resulted in a loss of membrane integrity of 16,38 and $55 \%$, respectively. For all metals tested, an inhibition of esterase activity, in a dose-dependent manner, was observed. Reduction of chlorophyll $a$ content, decrease of maximum quantum yield of photosystem II and modification of mitochondrial membrane potential was also verified. In conclusion, the exposure of $P$. subcapitata to metals resulted in a perturbation of the cell physiological status. Principal component analysis revealed that the impairment of esterase activity combined with the reduction of chlorophyll $a$ content were related with the inhibition of growth caused by a prolonged exposure to the heavy metals.
\end{abstract}

(C) 2015 Elsevier B.V. All rights reserved.

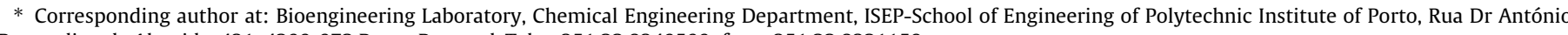
Bernardino de Almeida, 431, 4200-072 Porto, Portugal. Tel.: +351 22 8340500; fax: +351 228321159 .

E-mail address: evs@isep.ipp.pt (E.V. Soares). 


\section{Introduction}

Although heavy metals occur naturally, their presence in the environment is due, mostly, to anthropogenic activities. Since the industrial revolution, there has been an increasing use of heavy metals with the subsequent release into the environment and contamination of surface and groundwater. Metals are a cause of concern since they can provoke a detrimental effect on ecosystems and public health due to their toxicity and persistence in the environment. Several metals, such as copper and zinc, can have a dual role: at low concentration are essential to metabolism; at high concentration are toxic. Other metals, like $\mathrm{Pb}$ or $\mathrm{Hg}$, do not have any known cellular function [1].

High levels of cadmium ( $\geq 9 \mu \mathrm{mol} \mathrm{L}^{-1} \mathrm{Cd}$ ) can be found in polluted areas, such as in the vicinity of Cd-bearing deposits [2]. Cd is generally considered a non-essential element. Its toxicity seems to be associated to the high affinity to sulfhydryl groups, the displacement or substitution of essential metal ions (such as $\mathrm{Zn}$ ) and the modification of the conformation of the bio molecules [3]. Toxic effects of cadmium on algae include the inhibition of growth [4,5] and photosynthesis [6]. Cd affects the ultra-structure and photosynthesis of the unicellular freshwater green alga Micrasterias denticulata as a consequence of the disturbance of calcium homeostasis probably by displacement of Ca by Cd [7]. Cadmium induced the production of reactive oxygen species (ROS) [8] and activated the transcription of a large number of genes involved in the oxidative stress defence mechanisms in the alga Chlamydomonas reinhardtii [9].
In polluted rivers, chromium can be found at $17-140 \mu \mathrm{mol} \mathrm{L}^{-1}$ [10]. Chromium (III) and chromium (VI) are the two common oxidation states of chromium in the environment. Trivalent chromium is considered a micronutrient, essential for the proper function of living organisms, while hexavalent chromium can display toxic effects on biological systems. $\mathrm{Cr}(\mathrm{VI})$ crosses cellular membrane and exhibits strong oxidative potential [11]. In the alga Pseudokirchneriella subcapitata, $\mathrm{Cr}(\mathrm{VI})$ inhibited growth and induced genetic mutations [12]. $\mathrm{Cr}(\mathrm{VI})$ also induced the intracellular ROS accumulation in the alga $C$. reinhardtii [8]. Studies using transmission electron microscopy showed ultra-structural modifications (such as increased vacuolization, condensed cytoplasm and dark precipitation in the cell wall) in cells of the alga M. denticulata exposed to $\mathrm{Cr}(\mathrm{VI})$ during three weeks [13]. Proteomic analysis revealed that the treatment of $P$. subcapitata alga cells with $\mathrm{Cr}(\mathrm{VI})$ altered the expression of proteins associated with the metabolism of amino acids glutamine, arginine and methionine [14].

Copper concentrations as high as $1 \times 10^{3} \mu \mathrm{mol} \mathrm{L}^{-1}$ can be found in waters receiving drainage from mining operations and abandoned copper mines [15]. Cu, at low concentration, is an essential micronutrient for the metabolism of different organisms including cyanobacteria and algae. At high concentration, $\mathrm{Cu}$ induced toxic effects such as inhibition of growth, respiration and nitrate uptake and loss of membrane integrity $[16,17]$. Copper is a strong inhibitor of photosynthesis [17] and reduces total thiol content in Scenedesmus sp. [18]. Copper induced the intracellular ROS accumulation in P. subcapitata, Chlorella vulgaris and C. reinhardtii $[8,19]$,

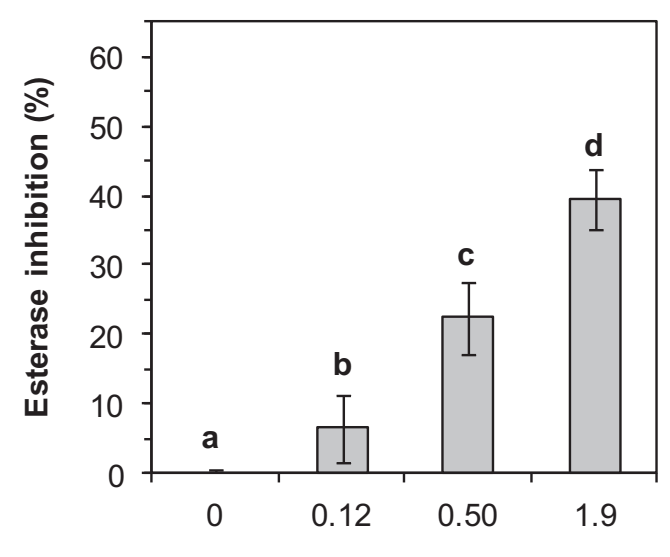

$[\mathrm{Cd}(\mathrm{II})]\left(\mu \mathrm{mol} \mathrm{L} \mathrm{L}^{-1}\right)$

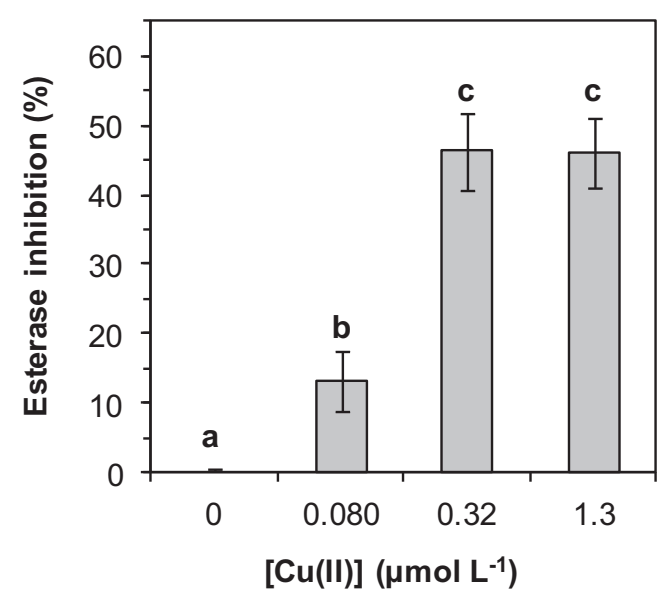

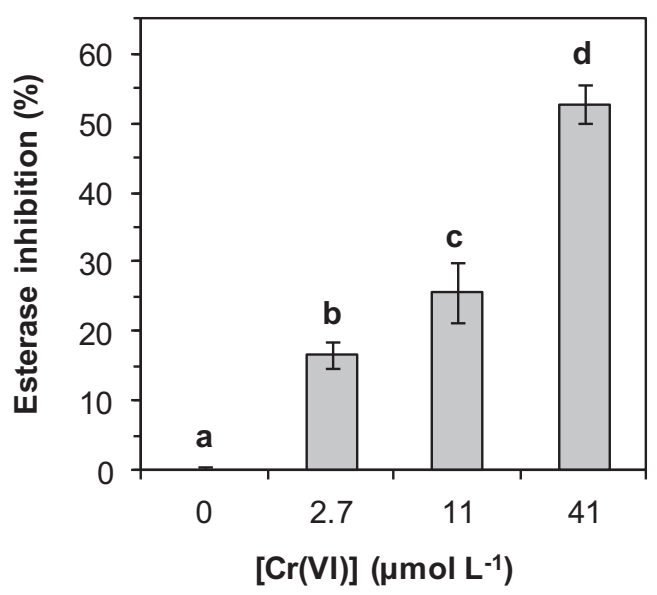

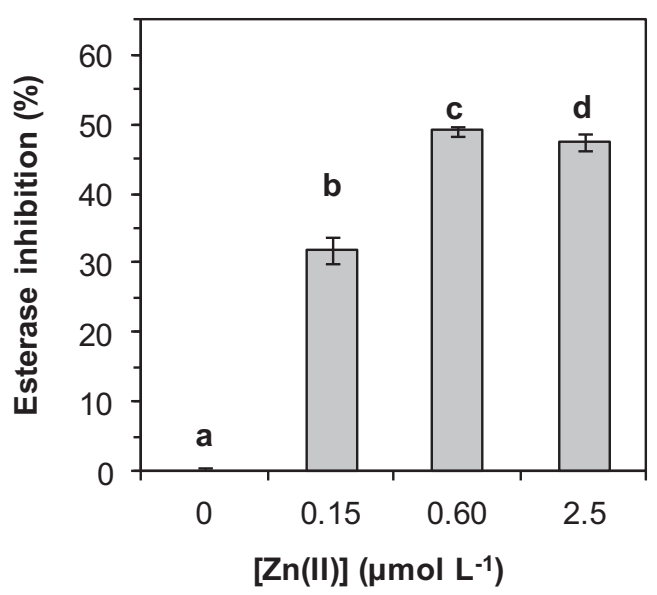

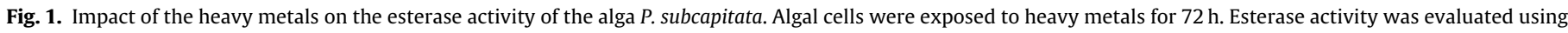

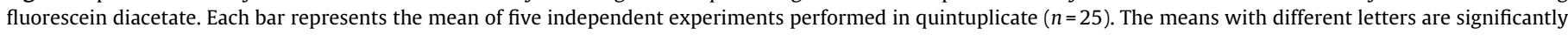
different $(P<0.05)$. 
as well as a strong up regulation of transcripts encoding enzymes associated with defence against oxidative stress [20].

Zinc is also a micronutrient required for many biological functions, which plays a structural and catalytic role in several enzymes [21]. In a polluted river, a zinc concentration of $172-667 \mu \mathrm{mol} \mathrm{L}^{-1}$ was found [10]. High $\mathrm{Zn}$ concentration can promote severe toxic effects, which include inhibition of photosynthetic activity in the cyanobacterium Synechocystis aquatilis [22] and in the green alga Scenedesmus sp. [18]. Inhibition of growth, respiration and nitrate uptake [17], as well as the reduction of thiol content in Scenedesmus sp. [18] was also described.

The worldwide industrialization occurred in 19th and 20th century. As a consequence, ecological problems increased and triggered the development of acute and chronic laboratory toxicity tests [23]. The green alga $P$. subcapitata has been widely used to assess the toxicity of substances and wastes due to its availability, ease of culture, ecological relevance and sensitivity to toxicants [24]. The standard procedures are based on the potential effects of the toxicant on the algal population growing exponentially during 72-96 $\mathrm{h}[25,26]$. The criterion most frequently used to evaluate the toxic effect is algal growth inhibition based on the change of biomass, determined by cell counts, dry weight or chlorophyll $a$ measurements [24]. Despite the use of $P$. subcapitata in the toxicity assessment, namely in heavy metals toxicity studies, the physiological causes that result in the growth inhibition of algal population are not completely known.

In the present study, our objective was to contribute for the elucidation of the main targets of heavy metals toxicity in the alga $P$. subcapitata. For this purpose, the impact of $\mathrm{Cd}(\mathrm{II}), \mathrm{Cr}(\mathrm{VI}), \mathrm{Cu}(\mathrm{II})$ and $\mathrm{Zn}$ (II) on membrane integrity, esterase activity, mitochondrial function, photosynthetic activity and chlorophyll $a$ content of the alga, exposed for $72 \mathrm{~h}$ to different concentrations of the toxicants, was evaluated. Principal component analysis (PCA) was carried out to determine the relationship among metabolic parameters and the growth inhibition of $P$. subcapitata cells exposed to different metals concentrations.

\section{Material and methods}

\subsection{Strain, media and culture conditions}

In this work, the freshwater green alga Pseudokirchneriella subcapitata (strain 278/4) was used. The original strain was obtained from the Culture Collection of Algae and Protozoa (CCAP), UK.

The starter-cultures were prepared weekly by inoculating a loop of algal cells (from an agar slant) in $20 \mathrm{~mL}$ OECD algal test medium [26], in $100 \mathrm{~mL}$ Erlenmeyer flasks. Cultures with an initial cell concentration of $5 \times 10^{4}$ cells $\mathrm{mL}^{-1}$ were inoculated from the pre-cultures (in mid-exponential phase of growth) and incubated for 2 days, at $25^{\circ} \mathrm{C}$, on an orbital shaker at $100 \mathrm{rpm}$, under continuous "cool white" fluorescent light, with an intensity of $55 \mu \mathrm{mol}$ photons $\mathrm{m}^{-2} \mathrm{~s}^{-1}$ at the surface of the flask, as previously described [27].

Cell concentration was determined as previously described [28].

\subsection{Metals exposure}

Based on previous growth inhibition assays [27], algal cultures with 2 days of growth were exposed to three nominal concentrations of each metal: a low concentration $\left[0.12 \mu \mathrm{mol} \mathrm{L}^{-1}\right.$ $\mathrm{Cd}(\mathrm{II}), 2.7 \mu \mathrm{mol} \mathrm{L}^{-1} \mathrm{Cr}(\mathrm{VI}), 0.080 \mu \mathrm{mol} \mathrm{L}^{-1} \mathrm{Cu}(\mathrm{II})$ and $0.15 \mu \mathrm{mol} \mathrm{L}^{-1}$ $\mathrm{Zn}(\mathrm{II})]$; an intermediate concentration $\left[0.50 \mu \mathrm{mol} \mathrm{L}^{-1} \mathrm{Cd}(\mathrm{II})\right.$, $11 \mu \mathrm{mol} \mathrm{L}^{-1} \mathrm{Cr}(\mathrm{VI}), 0.32 \mu \mathrm{mol} \mathrm{L}^{-1} \mathrm{Cu}(\mathrm{II})$ and $\left.0.60 \mu \mathrm{mol} \mathrm{L}^{-1} \mathrm{Zn}(\mathrm{II})\right]$ and a high concentration [1.9 $\mu \mathrm{mol} \mathrm{L}^{-1} \mathrm{Cd}(\mathrm{II}), 41 \mu \mathrm{mol} \mathrm{L}^{-1} \mathrm{Cr}(\mathrm{VI})$, $1.3 \mu \mathrm{mol} \mathrm{L}^{-1} \mathrm{Cu}(\mathrm{II})$ and $\left.2.5 \mu \mathrm{mol} \mathrm{L}^{-1} \mathrm{Zn}(\mathrm{II})\right]$. For this purpose,

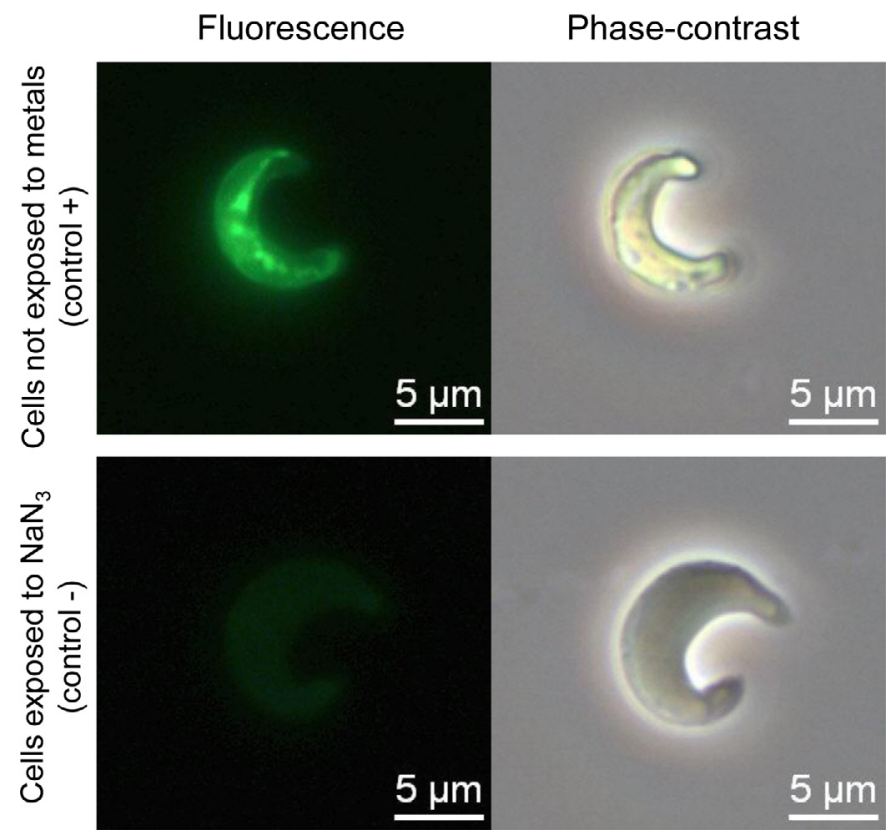

Fig. 2. Visualization of mitochondria of the alga P. subcapitata. Microphotographs illustrative of rhodamine 123 (Rh123) stained cells.

appropriate volumes of $\mathrm{CdCl}_{2}, \mathrm{~K}_{2} \mathrm{Cr}_{2} \mathrm{O}_{7}, \mathrm{Cu}\left(\mathrm{NO}_{3}\right)_{2}$, and $\mathrm{ZnCl}_{2}$ solutions were added from standard solutions (Merck) or from a primary standard of $\mathrm{K}_{2} \mathrm{Cr}_{2} \mathrm{O}_{7}$. Cells were incubated for $72 \mathrm{~h}$, in OECD medium, at $25^{\circ} \mathrm{C}$, on an orbital shaker at $100 \mathrm{rpm}$, under continuous light. In addition, control cultures were prepared without the addition of heavy metals.

Free metal concentrations (Table 1 ) were calculated using the MINEQL+ software (version 4.5) [29]. Computational studies were performed at $\mathrm{pH} 7.5$ considering the total heavy metals and ligands concentrations, as well as all the affinity constants between heavy metals and the different ligands and solubility product constants [30].

Table 1

Loss of cell membrane integrity (SYTOX Green positive cells) of the alga $P$. subcapitata, exposed to heavy metals for $72 \mathrm{~h}$, in function of total and free metal ion concentration.

\begin{tabular}{llll}
\hline Metal & $\begin{array}{l}\text { Total }[\mathrm{Me}] \\
\left(\mu \mathrm{mol} \mathrm{L}^{-1}\right)\end{array}$ & $\begin{array}{l}\text { Free }[\mathrm{Me}] \\
\left.(\mu \mathrm{mol} \mathrm{L})^{-1}\right)\end{array}$ & $\begin{array}{l}\text { SYTOX Green } \\
\text { positive cells }(\%)\end{array}$ \\
\hline Control & & & $0.5 \pm 0.2$ \\
& 0 & & ND \\
Cd(II) & & $2.4 \times 10^{-4}$ & $0.9 \pm 0.9$ \\
& 0.12 & 0.22 & $15.5 \pm 2.4$ \\
& 0.50 & 1.2 & \\
$\mathrm{Cr}(\mathrm{VI})$ & 1.9 & & $0.2 \pm 0.2$ \\
& 2.7 & 2.4 & $2.0 \pm 0.8$ \\
& 11 & 9.9 & $38.1 \pm 7.2$ \\
$\mathrm{Cu}(\mathrm{II})$ & 41 & 37 & $0.4 \pm 0.4$ \\
& $8.0 \times 10^{-2}$ & & $0.3 \pm 0.3$ \\
& 0.32 & $6.2 \times 10^{-7}$ & $55 \pm 2$ \\
$\mathrm{Zn}(\mathrm{II})$ & 1.3 & $7.6 \times 10^{-3}$ & $\mathrm{ND}$ \\
& & $7.8 \times 10^{-2}$ & $\mathrm{ND}$ \\
& 0.15 & & $1.3 \pm 0.5$ \\
& 0.60 & $7.2 \times 10^{-4}$ &
\end{tabular}

ND - not determined.

SYTOX Green positive cells mean values were obtained from at least three experiences performed in duplicate $(n \geq 6)$. 

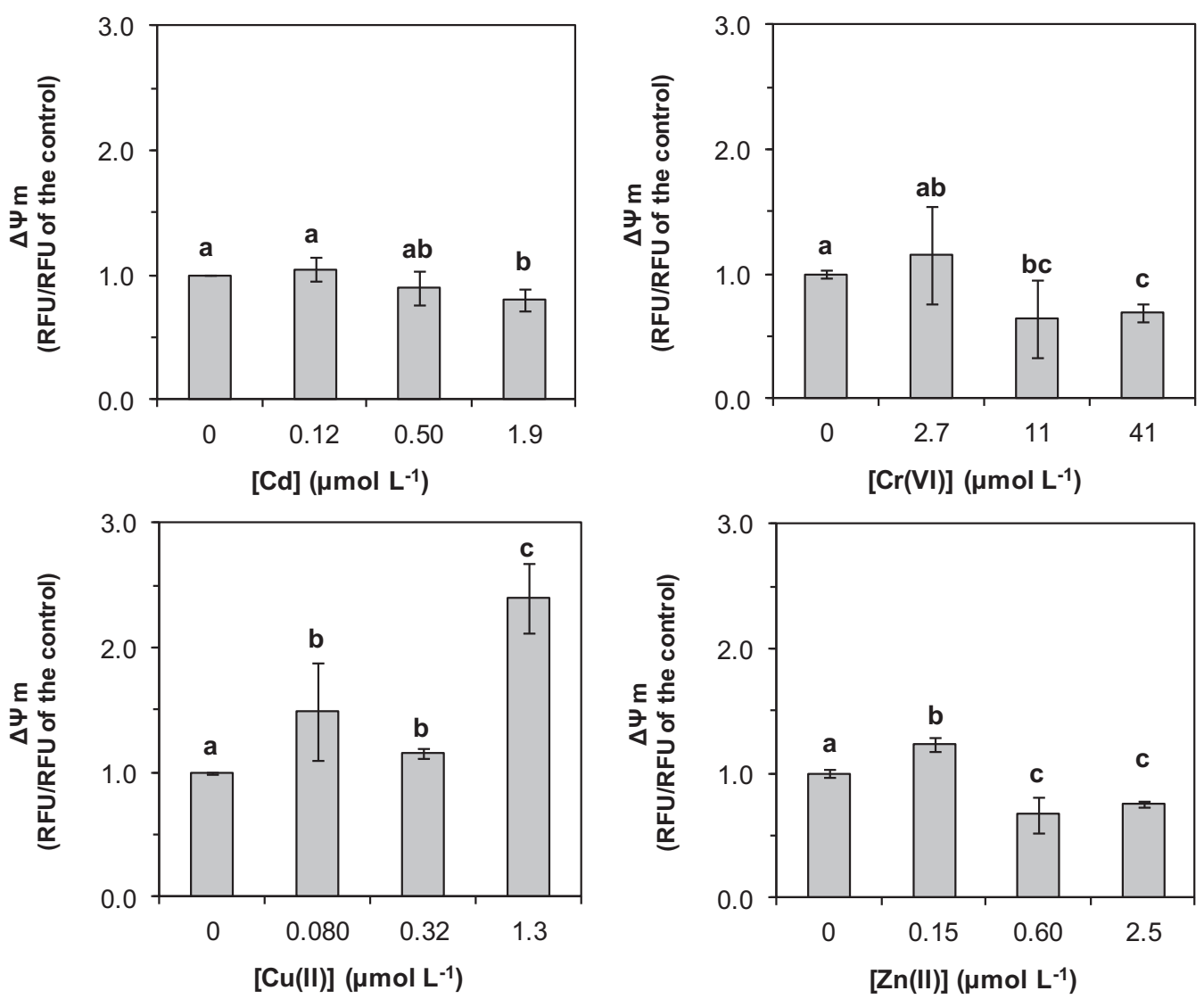

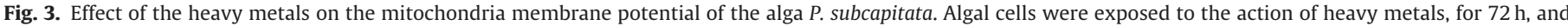

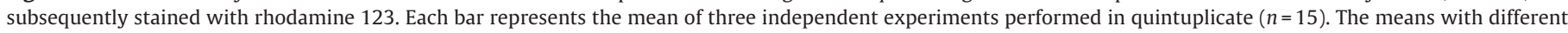
letters are significantly different $(P<0.05)$.

\subsection{Staining protocols}

After contact with metal, cells were harvested by centrifugation $(2500 \times g, 5 \mathrm{~min})$ and suspended in OECD medium (membrane integrity and esterase activity) or $100 \mathrm{mmol} \mathrm{L}^{-1}$ PBS buffer ( $\mathrm{pH} 7.0$ ) (mitochondrial activity).

Membrane integrity of algal cells was monitored with the dye SYTOX Green (SG) (Molecular Probes, Invitrogen). SG is excluded in $P$. subcapitata algal cells with intact membrane. Cells with a damaged plasma membrane are penetrated by the fluorescent probe, which displayed a marked green fluorescent [31]. Cells $\left(1 \times 10^{6} \mathrm{~mL}^{-1}\right)$ were incubated with $0.5 \mu \mathrm{mol} \mathrm{L}^{-1} \mathrm{SG}$, for $40 \mathrm{~min}$, at $25^{\circ} \mathrm{C}$, in the dark. The percentage of SG positive cells was determined by microscopy using a Leica DLMB epifluorescence microscope, equipped with a HBO-100 mercury lamp and a filter set GFP from Leica. In each experiment and for every metal concentration, four samples of at least 100 cells (total $>400$ cells) were scored in randomly selected microscope fields. As a positive control (cells with permeabilized membrane), algal cells were heated at $65^{\circ} \mathrm{C}$, for $1 \mathrm{~h}$.

Esterase activity was measured using fluorescein diacetate (FDA) (Sigma-Aldrich). Cells $\left(5 \times 10^{5} \mathrm{~mL}^{-1}\right)$ were stained with $20 \mu \mathrm{mol} \mathrm{L}^{-1} \mathrm{FDA}$, in the dark, at $25^{\circ} \mathrm{C}$, for $40 \mathrm{~min}$, as previously described [32]. Cell suspensions were dispensed in quintuplicate (200 $\mu \mathrm{L}$ per well) in a 96-well flat microplate (Orange Scientific). Fluorescence intensity was measured in a microplate reader at a fluorescence excitation wavelength of $485 / 14 \mathrm{~nm}$ and an emission wavelength of $535 / 25 \mathrm{~nm}$. Fluorescence was corrected (subtracting cell, culture medium and dye autofluorescence) and normalized considering the cell concentration. As negative control, algal cells were metabolically inactivated $\left(65^{\circ} \mathrm{C}\right.$, for $\left.1 \mathrm{~h}\right)$ and stained in the same conditions of live cells. The percentage of esterase inhibition was calculated as previously described [32].

Mitochondrial membrane potential $\left(\Delta \Psi_{\mathrm{m}}\right)$ was evaluated using rhodamine 123 (Rh123) (Sigma-Aldrich) as previously described [28]. Rh123 is a cell-permeant, cationic, probe that is concentrated by active mitochondria [33]. Cells $\left(1 \times 10^{6} \mathrm{~mL}^{-1}\right)$ were stained with $5 \mu \mathrm{mol} \mathrm{L}^{-1} \mathrm{Rh} 123$ solution, for $30 \mathrm{~min}$, at $25^{\circ} \mathrm{C}$, in the dark. After staining, cells were washed (two times) and suspended in PBS buffer. For each metal concentration, cells were dispensed in quintuplicate in a microplate and the fluorescence intensity was measured, corrected and normalized as described above (evaluation of esterase activity). Heavy metal toxicity was expressed as the ratio between the fluorescence in the assay and the fluorescence in the control (non-treated cells). As negative control, cells were treated with sodium azide $\left(\mathrm{NaN}_{3} ; 20 \mathrm{mmol} \mathrm{L}^{-1}\right)$ (Sigma-Aldrich), for $10 \mathrm{~min}$; subsequently, cells were stained with Rh123 as described above. The visualization of algal mitochondria was carried out using an epifluorescence microscope, equipped with a filter set GFP from Leica. Images were acquired with a Leica DC 300 F camera and processed using Leica IM 50-Image Manager software.

\subsection{Determination of photosynthetic efficiency and chlorophyll a content}

After metals exposure for $72 \mathrm{~h}$, cells were centrifuged $(2500 \times \mathrm{g}$, $5 \mathrm{~min}$ ) and resuspended in OECD medium at $1 \times 10^{7}$ cells $\mathrm{mL}^{-1}$.

Photosynthetic activity was assessed using a pulse amplitude modulated (PAM) fluorescence assay. Algal cells were dark adapted for $30 \mathrm{~min}$ and chlorophyll $a$ fluorescence was measured using a Walz JUNIOR-PAM chlorophyll fluorometer. PAM fluorometer 

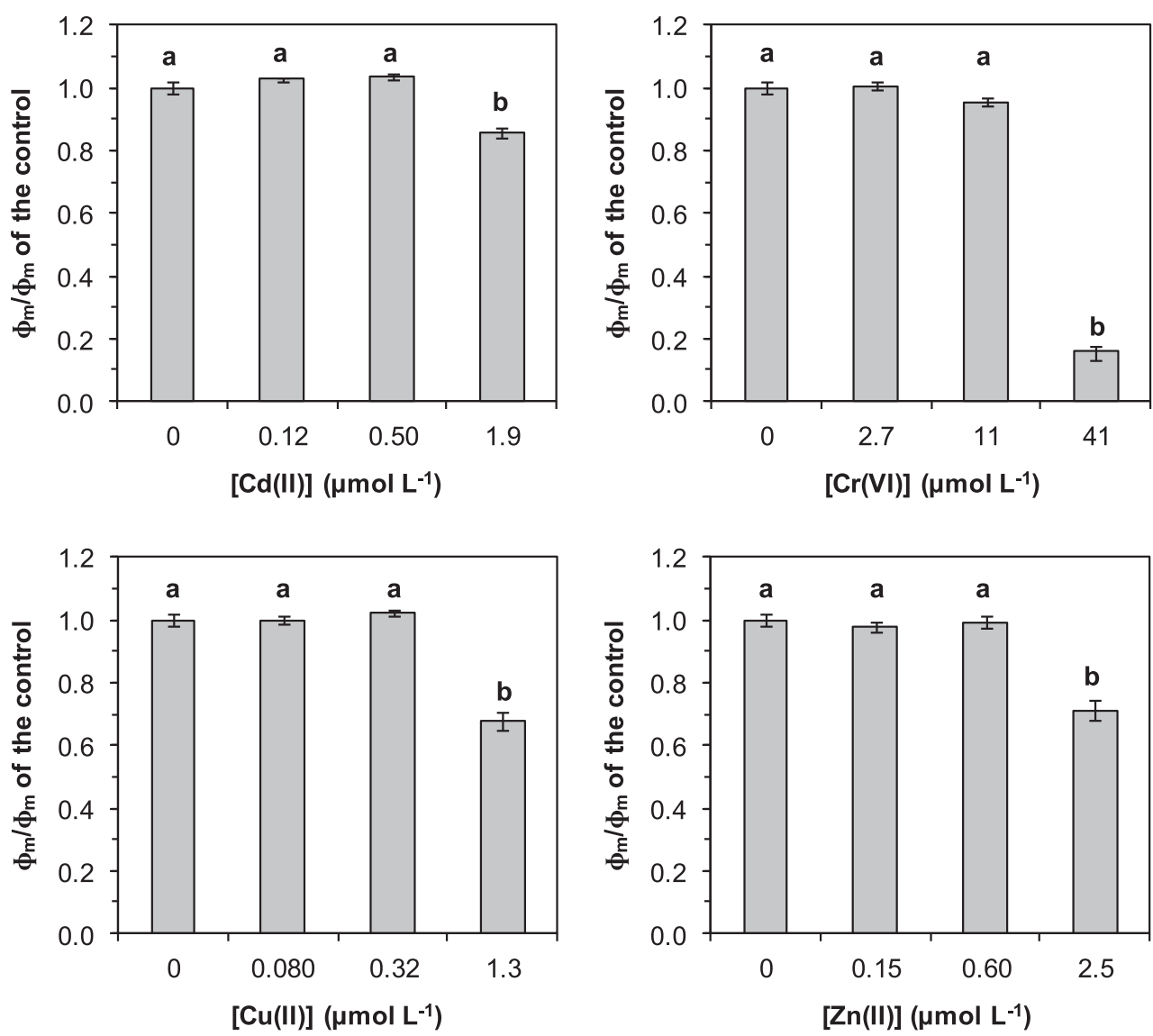

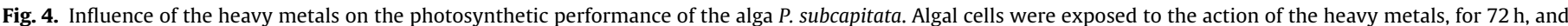

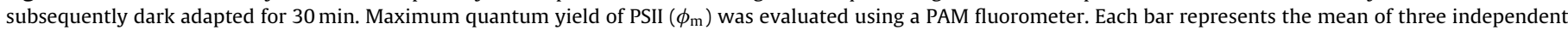
experiments performed in sevenfold $(n=21)$. The means with different letters are significantly different $(P<0.05)$.

measured the minimal fluorescence $\left(F_{0}\right)$ of dark-adapted cells and the maximum fluorescence $\left(F_{\mathrm{m}}\right)$ obtained with a saturating light pulse of $1500 \mu \mathrm{mol}$ photons $\mathrm{m}^{-2} \mathrm{~s}^{-1}$. The maximum quantum yield of PSII $\left(\phi_{\mathrm{m}}\right)$ was automatically calculated, using the WinControl software (version 3.2.2), as the ratio $F_{\mathrm{v}} / F_{\mathrm{m}}\left(F_{\mathrm{v}}\right.$ is variable fluorescence) from fluorescence values $F_{0}$ and $F_{\mathrm{m}}$ [34-36], according to the equation:

$\left(\Phi_{\mathrm{m}}\right)=\frac{F_{\mathrm{v}}}{F_{\mathrm{m}}}=\frac{\left(F_{\mathrm{m}}-F_{0}\right)}{F_{\mathrm{m}}}$

The maximum PSII quantum yield is a measure of intrinsic (maximum) efficiency of PSII, i.e., the quantum efficiency if all PSII centres were open. This $F_{\mathrm{v}} / F_{\mathrm{m}}$ ratio has been used as a sensitive indicator of the photosynthetic performance [35]. The impact of heavy metals on photosynthetic activity was expressed as ratio between the $\phi_{\mathrm{m}}$ in the assay and the $\phi_{\mathrm{m}}$ in the control.

The measurement of chlorophyll $a$ (chl $a$ ) content was carried out using a spectrophotometric method as previously described [37]. The values of absorbance were corrected, for turbidity, by subtracting the value of the absorbance at $750 \mathrm{~nm}$. Chl $a$ content was calculated as previously described [38]. The values of chl $a$ content were normalized considering the cell concentration. The impact of heavy metals on chl $a$ content was expressed as the ratio between chl $a$ content in the assay and chl $a$ content in the control (non-treated cells).

\subsection{Recovery studies}

After treatment for $72 \mathrm{~h}$ with metal, in OECD culture medium, cells were harvested by centrifugation $(2500 \times \mathrm{g}, 5 \mathrm{~min})$, washed (two times) and suspended in fresh OECD culture medium, at a density of $5 \times 10^{4}$ cells $\mathrm{mL}^{-1}$. The growth was monitored daily as described above [28].

\subsection{Reproducibility of the results and statistical analysis}

Data presented are mean values \pm SD (presented with 95\% confidence value) of three-six independent experiments carried out under identical conditions. Statistical differences between nontreated and treated algal cells with heavy metals were tested by one-way ANOVA followed by Tukey-Kramer multiple comparison method.

Principal component analysis (PCA) $[39,40]$ was carried out to determine the relationship among metabolic parameters (esterase activity, cell membrane integrity, maximum quantum yield of PSII, chlorophyll $a$ content and mitochondrial membrane potential) and the growth of $P$. subcapitata cells exposed to different metals concentrations (see above, Section 2.2). The PCA was performed with the software CANOCO (Microcomputer Power), version 4.5.

\section{Results}

The algal cells of $P$. subcapitata were exposed to three nominal concentrations of $\mathrm{Cd}(\mathrm{II}), \mathrm{Cr}(\mathrm{VI}), \mathrm{Cu}(\mathrm{II})$ and $\mathrm{Zn}(\mathrm{II})$, based on previous 

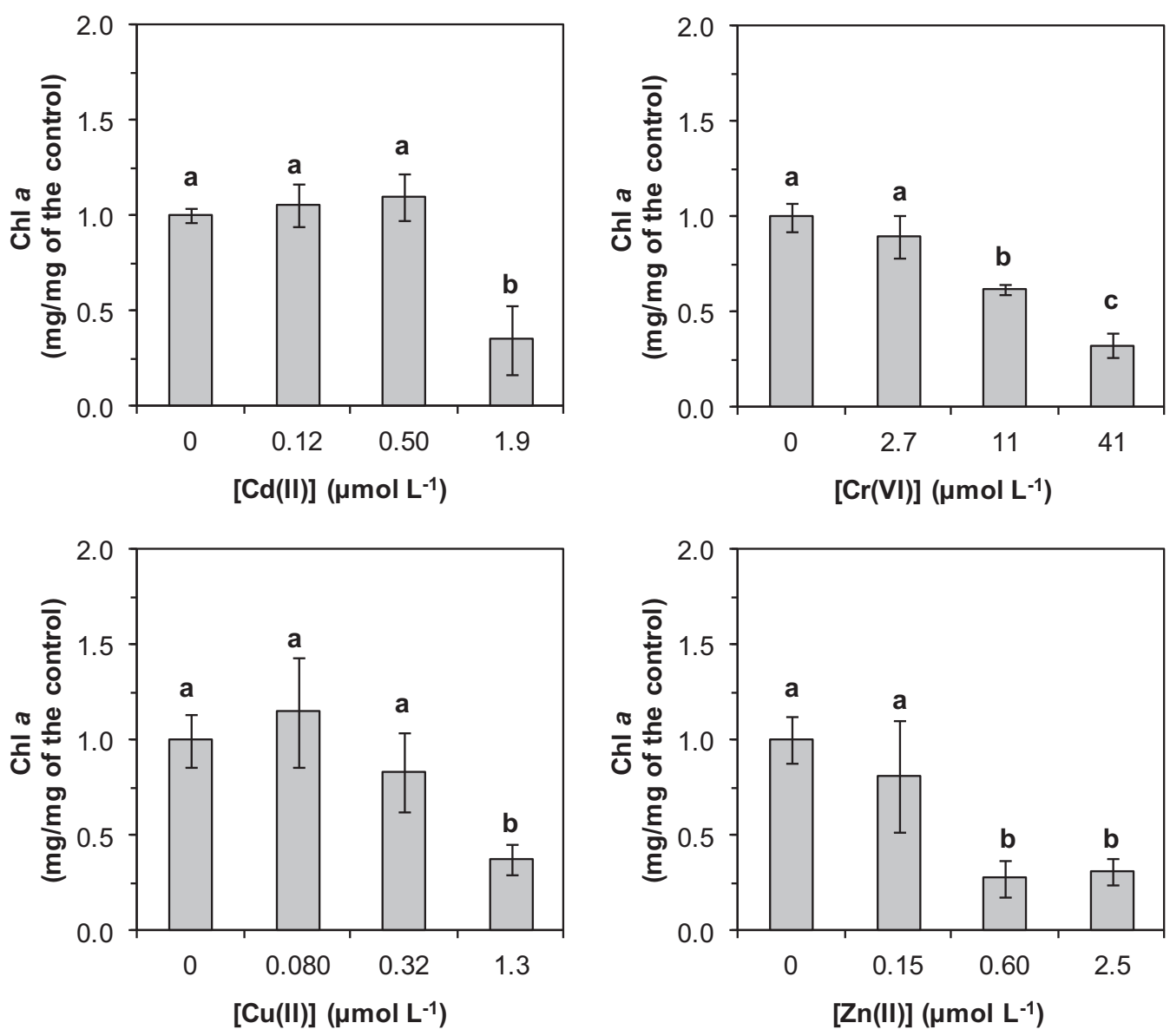

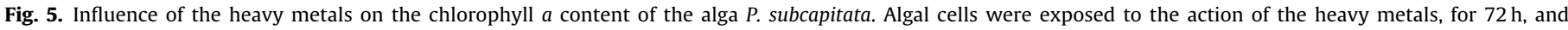

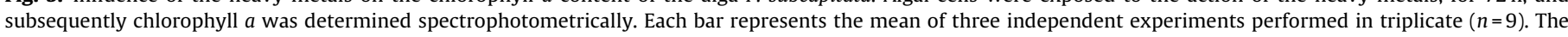
means with different letters are significantly different $(P<0.05)$.

growth inhibition assays [27]. Total and free metal ion concentrations are summarized in Table 1.

\subsection{Impact of heavy metals on cell membrane integrity}

Cell membrane integrity can be a critical target of the action of the pollutants. The exposure of $P$. subcapitata algal cells, in exponential phase of growth, to a low metal concentration $\left[2.7 \mu \mathrm{mol} \mathrm{L}^{-1}\right.$ $\mathrm{Cr}(\mathrm{VI})$ and $\left.8.0 \times 10^{-2} \mu \mathrm{mol} \mathrm{L}^{-1} \mathrm{Cu}(\mathrm{II})\right]$ did not induce a loss of cell membrane integrity (Table 1 ). Similarly, $\leq 2 \%$ of cell population loss membrane integrity (Table 1 ) when algal cells were exposed to heavy metals concentrations close to $72 \mathrm{~h}-\mathrm{EC}_{50}$ values [0.50 $\mu \mathrm{mol} \mathrm{L}^{-1} \mathrm{Cd}(\mathrm{II}), 11 \mu \mathrm{mol} \mathrm{L}^{-1} \mathrm{Cr}(\mathrm{VI})$ and $\left.0.32 \mu \mathrm{mol} \mathrm{L}^{-1} \mathrm{Cu}(\mathrm{II})\right]$. The exposure of algal cells to high concentrations $\left[1.9 \mu \mathrm{mol} \mathrm{L}^{-1}\right.$ $\mathrm{Cd}(\mathrm{II}), 41 \mu \mathrm{mol} \mathrm{L}^{-1} \mathrm{Cr}(\mathrm{VI})$ and $\left.1.3 \mu \mathrm{mol} \mathrm{L}^{-1} \mathrm{Cu}(\mathrm{II})\right]$ resulted in a loss of cell membrane integrity. $\mathrm{Zn}$ (II) did not induce a loss of membrane integrity up to $2.5 \mu \mathrm{mol} \mathrm{L}^{-1}$ (Table 1 ).

These results show that $\mathrm{Zn}(\mathrm{II})$ inhibited growth in the absence of damage of cell membrane integrity. $\mathrm{Cd}(\mathrm{II}), \mathrm{Cr}(\mathrm{VI})$ and $\mathrm{Cu}(\mathrm{II})$ induced a reduction of algal growth (10-50\%) in the absence of a loss of cell membrane integrity. Only the exposure to high concentration of these metals, where the growth was arrested, induced a loss of membrane integrity (Table 1 ). Algal cells exposed to $1.3 \mu \mathrm{mol} \mathrm{L}^{-1}$ $\mathrm{Cu}$ (II) for a short time period ( $30 \mathrm{~min}$ ) retained membrane integrity. This result indicated that the loss of membrane integrity occurred in cells exposed to high $\mathrm{Cu}(\mathrm{II})$ concentration $\left[1.3 \mu \mathrm{mol} \mathrm{L}^{-1} \mathrm{Cu}(\mathrm{II})\right]$ was not a rapid event. Together, these results prompted us to investigate the impact of heavy metals on algae metabolic activity.

\subsection{Impact of heavy metals on esterase activity and mitochondrial function}

The presence of $\mathrm{Cd}(\mathrm{II}), \mathrm{Cr}(\mathrm{VI}), \mathrm{Cu}(\mathrm{II})$ and $\mathrm{Zn}(\mathrm{II})$ reduced significantly $(P<0.05)$ the esterase activity in a dose-dependent manner (Fig. 1). Even for the lowest concentrations tested $\left[0.12 \mu \mathrm{mol} \mathrm{L}^{-1} \mathrm{Cd}(\mathrm{II}), \quad 2.7 \mu \mathrm{mol} \mathrm{L}^{-1} \mathrm{Cr}(\mathrm{VI}), \quad 8.0 \times 10^{-2} \mu \mathrm{mol} \mathrm{L}^{-1}\right.$ $\mathrm{Cu}(\mathrm{II})$ and $\left.0.15 \mu \mathrm{mol} \mathrm{L}^{-1} \mathrm{Zn}(\mathrm{II})\right]$, esterase activity was significantly $(P<0.05)$ reduced (Fig. 1$)$, which shows the high sensitivity of the esterases to the presence of metals.

In $P$. subcapitata algal cells, the mitochondria display a tubular arrangement along the inner face of the chloroplast as revealed by electron microscopy [41]. Mitochondrial morphology analysis by fluorescence microscopy, using the mitochondria-specific fluorescent dye rhodamine 123 (Rh123), confirmed this type of mitochondria morphology (Fig. 2).

Rh123 enters freely the cell by simple diffusion through the plasma membrane and is electrophoretically distributed in the mitochondrial matrix in response to mitochondrial membrane potential $\left(\Delta \Psi_{\mathrm{m}}\right)[42,43]$. It was shown that Rh123 is a reliable method for mitochondrial function studies with algal cells [44]. In this context, Rh123 was used to investigate the changes in the mitochondrial bioenergetics in response to the presence of heavy metals. The exposure of algal cells to all $\mathrm{Cu}(\mathrm{II})$ concentrations or $0.15 \mu \mathrm{mol} \mathrm{L}^{-1} \mathrm{Zn}(\mathrm{II})$ induced a significant $(P<0.05)$ increase in mitochondrial membrane potential $\left(\Delta \Psi_{\mathrm{m}}\right)$ (hyperpolarisation) (Fig. 3). The exposure to $1.9 \mu \mathrm{mol} \mathrm{L}^{-1} \mathrm{Cd}(\mathrm{II}), 11$ and $41 \mu \mathrm{mol} \mathrm{L}-1$ $\mathrm{Cr}(\mathrm{VI})$ or 0.60 and $2.5 \mu \mathrm{mol} \mathrm{L}^{-1} \mathrm{Zn}(\mathrm{II})$ induced a significant $(P<0.05)$ 

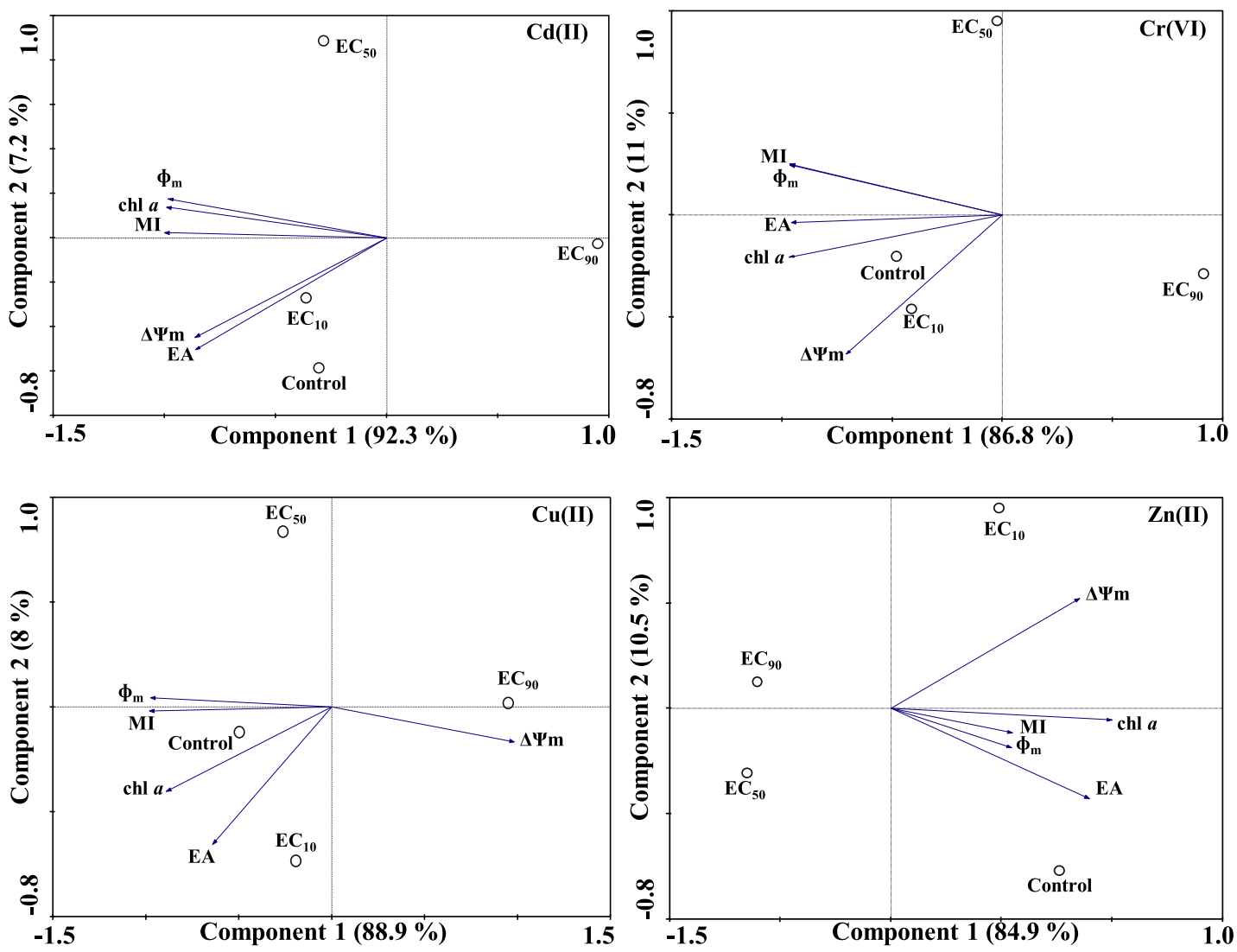

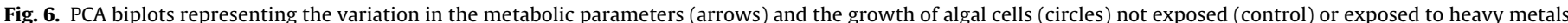

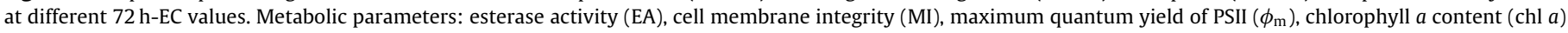
and mitochondrial membrane potential $\left(\Delta \Psi_{\mathrm{m}}\right)$.

reduction of the $\Delta \Psi_{\mathrm{m}}$ (Fig. 3). As negative control, algal cells were treated with $\mathrm{NaN}_{3}$ (inhibitor of mitochondrial electron transport chain). Cells treated with $\mathrm{NaN}_{3}$ displayed a very significant $(P<0.01)$ reduction of the $\Delta \Psi_{\mathrm{m}}$ (data not shown), comparatively to non-treated cells, and did not display fluorescent mitochondria upon staining with Rh123 (Fig. 2).

\subsection{Impact of heavy metals on photosynthetic activity and chlorophyll a content}

The effect of heavy metals on photosynthetic activity of algal cells was assessed using a pulse amplitude modulated (PAM) fluorescence assay. Non treated algal cells (control) displayed a maximum quantum yield of PSII $\left(\phi_{\mathrm{m}}\right)$ of $0.63 \pm 0.03(n=33)$, which is in agreement with the values described in the literature for P. subcapitata (0.62-0.64) $[45,46]$. The exposure of algal cells to the lowest [0.12 $\mu \mathrm{mol}-\mathrm{L}^{-1} \mathrm{Cd}(\mathrm{II}), 2.7 \mu \mathrm{mol} \mathrm{L}^{-1} \mathrm{Cr}(\mathrm{VI})$, $8.0 \times 10^{-2} \mu \mathrm{mol} \mathrm{L}^{-1} \mathrm{Cu}(\mathrm{II})$ and $\left.0.15 \mu \mathrm{mol} \mathrm{L}^{-1} \mathrm{Zn}(\mathrm{II})\right]$ or intermediary concentrations $\left[0.50 \mu \mathrm{mol} \mathrm{L}^{-1} \mathrm{Cd}(\mathrm{II}), 11 \mu \mathrm{mol} \mathrm{L}^{-1} \mathrm{Cr}(\mathrm{VI})\right.$, $0.32 \mu \mathrm{mol} \mathrm{L}^{-1} \mathrm{Cu}(\mathrm{II})$ and $\left.0.60 \mu \mathrm{mol} \mathrm{L}^{-1} \mathrm{Zn}(\mathrm{II})\right]$ of the different heavy metals did not provoke a significant $(P<0.05)$ modification of $\phi_{\mathrm{m}}$ (Fig. 4). Photosynthetic performance was significantly $(P<0.05)$ decreased when algal cells were incubated with the highest metal concentrations [1.9 $\mu \mathrm{mol} \mathrm{L}^{-1} \mathrm{Cd}(\mathrm{II}), 41 \mu \mathrm{mol} \mathrm{L}^{-1} \mathrm{Cr}(\mathrm{VI})$, $1.3 \times 10^{-2} \mu \mathrm{mol} \mathrm{L}^{-1} \mathrm{Cu}(\mathrm{II})$ and $\left.2.5 \mu \mathrm{mol} \mathrm{L}^{-1} \mathrm{Zn}(\mathrm{II})\right]$. This effect was markedly observed for $\mathrm{Cr}(\mathrm{VI})$ (Fig. 4).

The exposure of algal cells to the lowest concentrations of all metals did not modify significantly $(P<0.05)$ the chl $a$ content (Fig. 5). The incubation of algal cells with intermediary concentrations of $\mathrm{Cr}(\mathrm{VI})$ or $\mathrm{Zn}(\mathrm{II})$, provoked a significant reduction $(P<0.05)$ of the pigment (Fig. 5). The exposure of algal cells to the highest metals concentrations induced a significant reduction $(P<0.05)$ of the chl $a$ (Fig. 5).

Taken together, the results presented above suggest that photosynthesis was not affected for the lowest metals concentration, where a $10 \%$ growth reduction was observed. For the highest concentrations tested, which arrested algal growth, the photosynthesis was affected as revealed by the decrease of maximum quantum yield of PSII and the reduction of chl $a$ content. For intermediary values [0.50 $\mu \mathrm{mol} \mathrm{L}^{-1} \mathrm{Cd}(\mathrm{II}), 11 \mu \mathrm{mol} \mathrm{L}^{-1} \mathrm{Cr}(\mathrm{VI}), 0.32 \times 10^{-2} \mu \mathrm{mol} \mathrm{L}^{-1}$ $\mathrm{Cu}(\mathrm{II})$ and $\left.0.60 \mu \mathrm{mol} \mathrm{L}^{-1} \mathrm{Zn}(\mathrm{II})\right]$, the maximum quantum yield of PSII was not modified (Fig. 4); however, a reduction of chl $a$ content was observed for $\mathrm{Cr}(\mathrm{VI})$ and $\mathrm{Zn}$ (II) (Fig. 5).

\subsection{Variation among metabolic parameters and growth of algal cells exposed to metals}

In order to evaluate the weight of each metabolic parameter studied on the growth inhibition of algal cells exposed to heavy metals, a PCA was carried out. In the PCA biplots presented in Fig 6, each metabolic parameter is represented by an arrow. The arrow direction indicates the greatest change for each measured parameter, whereas the length of the arrow is related to the variation of each parameter among the analysed samples. Samples are represented by circles.

The variance of the metabolic parameters on the algal cells growth was plotted along axis 1 which depicted $92.3 \%, 86.8 \%, 88.9 \%$ and $84.9 \%$ of the total extracted variance for $\mathrm{Cd}(\mathrm{II}), \mathrm{Cr}(\mathrm{VI}), \mathrm{Cu}(\mathrm{II})$ and $\mathrm{Zn}(\mathrm{II})$, respectively (Fig. 6). For $\mathrm{Cr}(\mathrm{VI})$, the parameters most related to this variation were esterase activity (EA) and chlorophyll $a$ (chl $a$ ), which contributed to the separation of the control from cells exposed to different EC values, being $72 \mathrm{~h}-\mathrm{EC}_{90}$ the most 

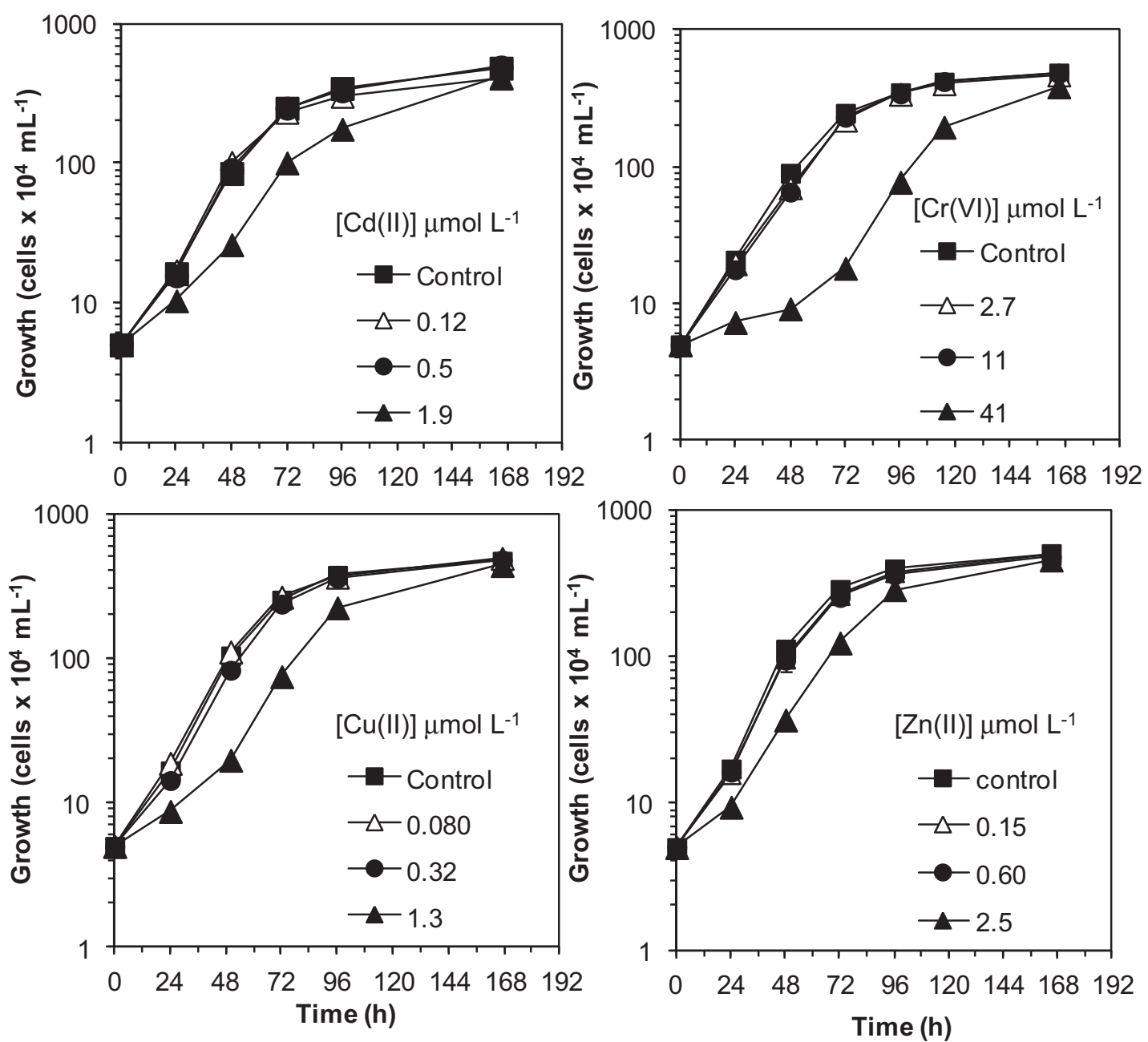

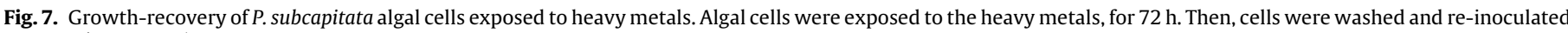
at $5 \times 10^{4}$ cells $\mathrm{mL}^{-1}$ in OECD medium. Each point represents the mean of two independent experiments performed in duplicate.

different (Fig. 6). The weight of these two metabolic parameters was corroborated when the PCA was done including only EA and chl $a$, describing $98.9 \%$ of total extracted variance of the samples; in this situation, a gradient according to the increase of metal concentration was observed (data not shown). Cd(II) biplot did not present a gradient that allow the separation of the samples according to metal concentration. Nevertheless, it was possible to observe that $72 \mathrm{~h}-\mathrm{EC}_{90}$ was the most different with the lowest values for all parameters (Fig. 6). The same distribution of samples was obtained when EA and chl $a$ were used in PCA (data not shown). In the case of $\mathrm{Cu}$ (II), it was not possible to separate all the samples. Only $72 \mathrm{~h}-\mathrm{EC}_{90}$ was distinct from the others (Fig. 6). The separation of the control and $72 \mathrm{~h}-\mathrm{EC}_{10}$ from the $72 \mathrm{~h}-\mathrm{EC}_{50}$ and $72 \mathrm{~h}-\mathrm{EC}_{90}$ was possible when the PCA was done only with the FDA and chl $a$, demonstrating the sensitivity of these two metabolic parameters to metal concentration (data not shown). Zn(II) biplot showed that EA, chl $a$ and mitochondrial membrane potential $\left(\Delta \Psi_{\mathrm{m}}\right)$ had a higher contribute to the variation among the analyzed samples (higher arrows) (Fig. 6). Nevertheless, these metabolic parameters did not create a gradient of sensitivity with the increase of metal concentration. Two groups are depicted in the biplot: one group which included control and $72 \mathrm{~h}-\mathrm{EC}_{10}$; and the other group composed by $72 \mathrm{~h}-\mathrm{EC}_{50}$ and $72 \mathrm{~h}-\mathrm{EC}_{90}$, with higher and lower values of EA, chl $a$ and $\Delta \Psi_{\mathrm{m}}$, respectively (Fig. 6). When only EA and chl $a$ were included in the PCA, the percentage of variance depicted along axis 1 increased to $96.8 \%$; control and $72 \mathrm{~h}-\mathrm{EC}_{10}$ were more separated along this axis (data not shown).

\subsection{Recovery assays}

After exposure, for $72 \mathrm{~h}$, to the action of different heavy metals, algal cells were washed and suspended in fresh culture medium at $5 \times 10^{4}$ cells $\mathrm{mL}^{-1}$. The exposure to heavy metals provoked a loss of esterase activity (Fig. 1), in all conditions tested. However, cells were able to resume the growth in a similar way to the control (cells not exposed to heavy metal) (Fig. 7). These results are consistent with those obtained with SYTOX Green, where no loss of membrane integrity was observed when the cells were exposed to $72 \mathrm{~h}-\mathrm{EC}_{10}$ and $72 \mathrm{~h}-\mathrm{EC}_{50}$ heavy metals values (Table 1 ). Cells exposed to the highest concentration of the different heavy metals $\left[1.9 \mu \mathrm{mol} \mathrm{L}^{-1} \mathrm{Cd}(\mathrm{II}), 41 \mu \mathrm{mol} \mathrm{L}^{-1} \mathrm{Cr}(\mathrm{VI}), 1.3 \mu \mathrm{mol} \mathrm{L}^{-1} \mathrm{Cu}(\mathrm{II})\right.$ and $\left.2.5 \mu \mathrm{mol} \mathrm{L}^{-1} \mathrm{Zn}(\mathrm{II})\right]$ re-started the growth more slowly, comparatively to the control (Fig. 7).

\section{Discussion}

Algae are in the base of food chain and stand in the front line of the aquatic pollution exposure. The impact of three concentrations of $\mathrm{Cd}(\mathrm{II}), \mathrm{Cr}(\mathrm{VI}), \mathrm{Cu}(\mathrm{II})$ and $\mathrm{Zn}(\mathrm{II})$ on the membrane integrity, metabolic activity and photosynthesis of the alga $P$. subcapitata was investigated.

Metal ions can provoke membrane damage and lead to disruption of cellular homeostasis [47]. In the present study, the exposure to high metal concentration $\left[1.9 \mu \mathrm{mol} \mathrm{L}^{-1} \mathrm{Cd}(\mathrm{II}), 41 \mu \mathrm{mol} \mathrm{L}^{-1}\right.$ $\mathrm{Cr}(\mathrm{VI})$ and $\left.1.3 \mu \mathrm{molL}^{-1} \mathrm{Cu}(\mathrm{II})\right]$ for $72 \mathrm{~h}$ induced the loss of 
membrane integrity. This effect is particularly noticeable for $\mathrm{Cu}(\mathrm{II})$ and $\mathrm{Cr}(\mathrm{VI})$ (Table 1). Cid et al. [16] observed that the marine diatom Phaeodactylum tricornutum population presented $41 \%$ cells with compromised membrane when treated with $8 \mu \mathrm{mol} \mathrm{L}^{-1} \mathrm{Cu}(\mathrm{II})$ for 72 h. The results presented here show the high sensitivity of $P$. subcapitata to $\mathrm{Cu}$ (II) since an higher percentage of cells (55\%) displayed disrupted plasma membrane with a lower $\left(1.3 \mu \mathrm{mol} \mathrm{L}^{-1}\right)$ $\mathrm{Cu}(\mathrm{II})$ concentration (Table 1 ). The loss of cell membrane integrity in algal cells exposed for $72 \mathrm{~h}$ at high concentrations of $\mathrm{Cr}(\mathrm{VI})$ and $\mathrm{Cu}(\mathrm{II})$ can explain, at least partially, the delay of growth recovery (Fig. 7). In fact, in the beginning of the recovery assay, only 62 and $45 \%$ of the cells presented intact membrane, after being exposed to $\mathrm{Cr}(\mathrm{VI})$ and $\mathrm{Cu}(\mathrm{II})$, respectively.

The cellular membrane, should not be the primary/immediate target of the action of the metals studied, by the following reasons: (i) all metal tested induced a growth inhibition of $10-50 \%$ without loss of membrane integrity; (ii) the exposure of algal cells to high metals concentrations [1.9 $\mu \mathrm{mol} \mathrm{L}^{-1} \mathrm{Cd}(\mathrm{II}), 41 \mu \mathrm{mol} \mathrm{L}^{-1} \mathrm{Cr}(\mathrm{VI})$ and $2.5 \mu \mathrm{mol} \mathrm{L}^{-1} \mathrm{Zn}(\mathrm{II})$ ], for $6 \mathrm{~h}$, did not induce the loss of membrane integrity [28]; a similarly result was obtained when algal cells were exposed to $1.3 \mu \mathrm{mol} \mathrm{L}^{-1} \mathrm{Cu}$ (II) for $30 \mathrm{~min}$. These results strongly suggest that the disruption of membrane integrity, observed for high metals concentrations, was not a rapid event. Probably, the metals induced the reduction of algal growth and metabolic activity; subsequently, occurred the loss of membrane integrity in a so called route from "live" to "dead" [48].

The activity of intracellular esterases was assessed using FDA as a substrate. FDA is hydrolysed by esterases to fluorescein, which exhibits a green fluorescence. Thus, the fluorescence intensity depends primarily on the esterase activity of the cells and reflects the functional (metabolic) status of the living cell [49,50]. Cd(II), $\mathrm{Cr}(\mathrm{VI}), \mathrm{Cu}(\mathrm{II})$ and $\mathrm{Zn}(\mathrm{II})$ inhibited the esterase activity of the algal cells of $P$. subcapitata, in a dose-dependent manner (Fig. 1). These results are consistent with those describing a loss of esterase activity after a short time exposure (1-6h) of the alga $P$. subcapitata to $\mathrm{Cu}(\mathrm{II})[28,32,51,52], \mathrm{Cd}(\mathrm{II})$ or $\mathrm{Zn}(\mathrm{II})[28,52]$. These metals may interact with the active centre of esterases or modify the conformation of the enzymes, provoking a decrease of the esterasic activity. The results presented here show the high sensitivity of these enzymes to the presence of heavy metals and reinforce the potential usefulness of the measurement of esterase activity of algal cells as an alternative endpoint for the detection of metal toxic effect.

Mitochondria are the only known organelle that displays a strong membrane potential $\left(\Delta \Psi_{\mathrm{m}}\right)$, with a negative charge inside. The movement of electrons through the electron transport chain in the inner mitochondrial membrane originates a transmembrane electrochemical gradient necessary for ATP production by ATP synthase [53]. Thus, $\Delta \Psi_{\mathrm{m}}$ reflects the mitochondrial activity. In the present work, Rh123 was used to evaluate the mitochondrial bioenergetics of $P$. subcapitata algal cells exposed to different heavy metals. This fluorescent probe have been used in mitochondrial function studies with a variety of cell types, such as animal [54,55], plant [56], yeast [43] and algal cells [57,58]. In recent years, bioenergetic studies in algal cells carried out with Rh123 were validated using a polarographic oxygen electrode [44].

The inhibition of ATP synthase, by oligomycin, resulted in an increase of $\Delta \Psi_{\mathrm{m}}$ and, consequently, an augment of mitochondrial staining with Rh123 [43]. Similarly, the exposure of $P$. subcapitata algal cells to all $\mathrm{Cu}(\mathrm{II})$ concentrations or $0.15 \mu \mathrm{mol} \mathrm{L}^{-1} \mathrm{Zn}(\mathrm{II})$ provoked an increase of mitochondrial fluorescence (Fig. 3), which can be attributed to the damage of mitochondrial function (energy production). An analogous effect (enhancement of $\Psi \mathrm{m}$ ) was described in the freshwater alga Scenedesmus obliquus exposed to perfluorocarboxilic and perfluorosulfonic acids for $72 \mathrm{~h}$ [57].

The treatment of $P$. subcapitata cells with sodium azide (electron transport chain inhibitor) originated the abolition of mitochondrial respiratory function with the consequent reduction of $\Delta \Psi_{\mathrm{m}}$. Under this condition, Rh123 accumulation was practically abolished (Fig. 2). Cd(II) and $\mathrm{Cr}(\mathrm{VI})$ at defined concentrations seems to have a similar effect. $P$. subcapitata cells exposed to $1.9 \mu \mathrm{mol} \mathrm{L}^{-1}$ $\mathrm{Cd}(\mathrm{II}), 11$ or $41 \mu \mathrm{mol} \mathrm{L}^{-1} \mathrm{Cr}(\mathrm{VI})$, displayed a reduction of mitochondrial staining with Rh123 (Fig. 3). The impact of $\mathrm{Zn}$ (II) on mitochondrial function was concentration dependent. At low concentrations, an increase of $\Delta \Psi_{\mathrm{m}}$ was observed; at intermediate and high concentrations, a reduction of $\Delta \Psi_{\mathrm{m}}$ occurred (Fig. 3). A similar pattern of perturbation of mitochondrial function was described by Brickley et al. [44] in C. reinhardtii exposed to an herbicide.

Photosynthetic pigments are organized in clusters called photosystem I (PSI) and photosystem II (PSII). The maximum quantum yield of PSII $\left(\phi_{\mathrm{m}}\right)$ allows to indicate the potential capacity of photosynthetic cells to convert light energy into chemical energy [59]. At higher concentrations [ $1.9 \mu \mathrm{mol} \mathrm{L}^{-1} \mathrm{Cd}(\mathrm{II}), 41 \mu \mathrm{mol} \mathrm{L}^{-1} \mathrm{Cr}(\mathrm{VI})$, $1.3 \mu \mathrm{mol} \mathrm{L}^{-1} \mathrm{Cu}$ (II) and $\left.2.5 \mu \mathrm{mol} \mathrm{L}^{-1} \mathrm{Zn}(\mathrm{II})\right]$, the metals tested provoked a perturbation on algal photosynthesis, as revealed by the reduction of $\phi_{\mathrm{m}}$ (Fig. 4), which was accompanied to the decrease of chl a content (Fig. 5). Similarly, a reduction of $30 \%$ of $\phi_{\mathrm{m}}$ in $P$. subcapitata exposed to $0.16 \mu \mathrm{mol} \mathrm{L}^{-1} \mathrm{Cu}$ for $96 \mathrm{~h}$ was described [59]. Studies with Chlorella pyrenoidosa also showed a reduction of maximum quantum yield when algal cells were exposed for $96 \mathrm{~h}$ to $\mathrm{Cd}$ (II) [60] or $\mathrm{Cr}(\mathrm{VI})$ [61]. The exposure of $M$. denticulata to $150 \mu \mathrm{mol} \mathrm{L}^{-1} \mathrm{Cd}$ for 4 days, inhibited almost completely the function of PSII [7]. The inhibition of the activity of PSII in the cyanobacterium $S$. aquatilis, exposed to $\mathrm{Zn}(\mathrm{II})$, was also described [22]. Additionally, the reduction of chl $a$ content was also observed in the alga Scenedesmus sp. exposed to $\mathrm{Cu}\left(2.5\right.$ and $\left.10 \mu \mathrm{mol} \mathrm{L}^{-1}\right)$ and $\mathrm{Zn}\left(5\right.$ and $25 \mu \mathrm{mol} \mathrm{L}^{-1}$ ) [17]. Probably, heavy metals inhibit chl $a$ biosynthesis [62].

The exposure of algal cells to $11 \mu \mathrm{mol} \mathrm{L}^{-1} \mathrm{Cr}(\mathrm{VI})$ or $0.60 \mu \mathrm{mol} \mathrm{L}^{-1} \mathrm{Zn}(\mathrm{II})$ did not affect, significantly $(P<0.05)$ the $\phi_{\mathrm{m}}$; however, a decrease of chl $a$ content was observed (Fig. 4 and 5 ), which suggest a different adaptation response to heavy metals stress. The results here presented are in agreement with those which describe that $\mathrm{Cr}(\mathrm{VI})$, at $\sim 7 \mu \mathrm{mol} \mathrm{L}^{-1}$, induced a decrease in chl $a$ and chl $b$ as well as down-regulated photosynthetic proteins in P. subcapitata [14].

In conclusion, the exposure of $P$. subcapitata to $\mathrm{Cd}(\mathrm{II}), \mathrm{Cr}(\mathrm{VI})$, $\mathrm{Cu}(\mathrm{II})$ and $\mathrm{Zn}(\mathrm{II})$, for $72 \mathrm{~h}$, had a negative impact on alga physiology and metabolism. Although a compromising of membrane integrity was observed for higher concentrations of $\mathrm{Cd}(\mathrm{II}), \mathrm{Cr}(\mathrm{VI})$ and $\mathrm{Cu}(\mathrm{II})$, cell membrane should not be the primary target of the action of metals. The main toxicity targets of the heavy metals under study have an intracellular localization. The PCA biplots revealed that the inhibition of esterase activity combined with the reduction of chlorophyll $a$ content were related to the growth inhibition caused by the prolonged exposure ( $72 \mathrm{~h}$ ) to $\mathrm{Cr}(\mathrm{VI})$ and $\mathrm{Cu}$ (II). In the case of $\mathrm{Zn}$ (II), in addition to these metabolic parameters, the damage of mitochondrial function (with the consequent impairment of energy production) was related with the growth inhibition caused by the exposure to this metal. The identification of the targets of the heavy metals studied contributes to the elucidation of the mechanisms of action of these toxicants on the alga $P$. subcapitata.

\section{Conflict of interest}

Authors declare no conflict of interest.

\section{Acknowledgments}

The authors thank the FCT Strategic Project PEstOE/EQB/LA0023/2013 and the Project "Biolnd-Biotechnology and Bioengineering for improved Industrial and Agro-Food processes", REF. NORTE-07-0124-FEDER-000028 Co-funded by the 
Programa Operacional Regional do Norte (ON.2-O Novo Norte), QREN, FEDER. Manuela D. Machado and Ana R. Lopes gratefully acknowledge the post-doctoral grants SFRH/BPD/72816/2010 and SFRH/BPD/92894/2013, from FCT, respectively. The authors also thank to Professor Vitor M. Vasconcelos and Doctor Francisco Arenas, from CIIMAR, for the use of JUNIOR-PAM chlorophyll fluorometer and technical assistance, respectively, and to Doctor Helena M.V.M. Soares and Doctor Olga C. Nunes, from Faculty of Engineering of Porto University, for the use of MINEQL+ and CANOCO software, respectively.

\section{References}

[1] G.M. Gadd, Metals, minerals and microbes: geomicrobiology and bioremediation, Microbiology 156 (2010) 609-643.

[2] ATSDR, Toxicological profile for cadmium, in, Agency for Toxic Substances and Disease Registry (ATSDR). U.S. Department of Health and Human Services -Public Health Service, 2012.

[3] S. Le Faucheur, R. Behra, L. Sigg, Phytochelatin induction, cadmium accumulation, and algal sensitivity to free cadmium ion in Scenedesmus vacuolatus, Environ. Toxicol. Chem. 24 (2005) 1731-1737.

[4] T. Kallqvist, Effect of water hardness on the toxicity of cadmium to the green alga Pseudokirchneriella subcapitata in an artificial growth medium and nutrient-spiked natural lake waters, J. Toxicol. Environ. Health A 72 (2009) 277-283.

[5] E. Torres, A. Cid, C. Herrero, J. Abalde, Effect of cadmium on growth ATP content carbon fixation and ultrastructure in the marine diatom Phaeodactylum tricornutum Bohlin, Water Air Soil Pollut. 117 (2000) 1-14.

[6] D.P. Singh, S.K. Sharma, P.S. Bisen, Differential action of $\mathrm{Hg}^{2+}$ and $\mathrm{Cd}^{2+}$ on the phycobilisomes and chlorophyll $a$ fluorescence, and photosystem-II dependent electron-transport in the cyanobacterium Anabaena flos-aquae, Biometals 6 (1993) 125-132.

[7] A. Andosch, M.J. Affenzeller, C. Lutz, U. Lutz-Meindl, A freshwater green alga under cadmium stress: ameliorating calcium effects on ultrastructure and photosynthesis in the unicellular model Micrasterias, J. Plant Physiol. 169 (2012) 1489-1500.

[8] I. Szivak, R. Behra, L. Sigg, Metal-induced reactive oxygen species production in Chlamydomonas Reinhardtii (Chlorophyceae), J. Phycol. 45 (2009) 427-435.

[9] A. Jamers, R. Blust, W. De Coen, J.L. Griffin, O.A.H. Jones, An omics based assessment of cadmium toxicity in the green alga Chlamydomonas reinhardtii Aquat. Toxicol. 126 (2013) 355-364.

[10] H.A. Shakir, J.I. Qazi, A.S. Chaudhry, Monitoring the impact of urban effluents on mineral contents of water and sediments of four sites of the river Ravi, Lahore, Environ. Monit. Assess. 185 (2013) 9705-9715.

[11] J. Kotas, Z. Stasicka, Chromium occurrence in the environment and methods of its speciation, Environ. Pollut. 107 (2000) 263-283.

[12] M. Labra, M. Bernasconi, F. Grassi, F. De Mattia, S. Sgorbati, R. Airoldi, S. Citterio, Toxic and genotoxic effects of potassium dichromate in Pseudokirchneriella subcapitata detected by microscopy and AFLP marker analysis, Aquat. Bot. 86 (2007) 229-235.

[13] S. Volland, C. Lutz, B. Michalke, U. Lutz-Meindl, Intracellular chromium localization and cell physiological response in the unicellular alga Micrasterias, Aquat. Toxicol. 109 (2012) 59-69.

[14] C. Vannini, M. Marsoni, G. Domingo, F. Antognoni, S. Biondi, M. Bracale, Proteomic analysis of chromate-induced modifications in Pseudokirchneriella subcapitata, Chemosphere 76 (2009) 1372-1379.

[15] ATSDR, Toxicological profile for copper, in, Agency for Toxic Substances and Disease Registry (ATSDR). U.S. Department of Health and Human Services -Public Health Service, 2004.

[16] A. Cid, P. Fidalgo, C. Herrero, J. Abalde, Toxic action of copper on the membrane system of a marine diatom measured by flow cytometry, Cytometry 25 (1996) 32-36.

[17] B.N. Tripathi, J.P. Gaur, Physiological behavior of Scenedesmus sp. during exposure to elevated levels of $\mathrm{Cu}$ and $\mathrm{Zn}$ and after withdrawal of metal stress, Protoplasma 229 (2006) 1-9.

[18] B.N. Tripathi, S.K. Mehta, A. Amar, J.P. Gaur, Oxidative stress in Scenedesmus sp. during short- and long-term exposure to $\mathrm{Cu}^{2+}$ and $\mathrm{Zn}^{2+}$, Chemosphere 62 (2006) 538-544.

[19] S. Knauert, K. Knauer, The role of reactive oxygen species in copper toxicity to two freshwater green algae, J. Phycol. 44 (2008) 311-319.

[20] A. Jamers, K. Van der Ven, L. Moens, J. Robbens, G. Potters, Y. Guisez, R. Blust, W. De Coen, Effect of copper exposure on gene expression profiles in Chlamydomonas reinhardtii based on microarray analysis, Aquat. Toxicol. 80 (2006) 249-260

[21] W.N. Lipscomb, N. Strater, Recent advances in zinc enzymology, Chem. Rev 96 (1996) 2375-2433.

[22] R.M. Chaloub, C.C.P. de Magalhaes, C.P. dos Santos, Early toxic effects of zinc on PSII of Synechocystis aquatilis f. aquatilis (Cyanophyceae), J. Phycol. 41 (2005) 1162-1168.

[23] C. Blaise, J.-F. Férard, Overview of contemporary toxicity testing, in: C. Blaise, J.F. Férard (Eds.), Small-Scale Freshwater Toxicity Investigations, Springer, Dordrecht, The Netherlands, 2005, pp. 1-68.
[24] C.R. Janssen, D.G. Heijerick, Algal toxicity tests for environmental risk assessments of metals, in: Reviews of Environmental Contamination and Toxicology, Springer, New York, 2003, pp. 23-52.

[25] US-EPA, Short-term Methods for Estimating the Chronic Toxicity of Effluents and Receiving Waters to Freshwater Organisms, 4th Edition, Environmental Protection Agency, Washington, DC, 2002, pp. 1-350, EPA-821-R-02-013.

[26] OECD, Alga, growth inhibition test (201), in: OECD Guideline for Testing of Chemicals, Organization for Economic Co-Operation and Development, Paris, France, 2011

[27] M.D. Machado, E.V. Soares, Modification of cell volume and proliferative capacity of Pseudokirchneriella subcapitata cells exposed to metal stress, Aquat. Toxicol. 147 (2014) 1-6.

[28] M.D. Machado, E.V. Soares, Use of a fluorescence-based approach to assess short-term responses of the alga Pseudokirchneriella subcapitata to metal stress, J. Appl. Phycol. 27 (2015) 805-813.

[29] W.D. Schecher, D.C. McAvoy, MINEQL+: A Chemical Equilibrium Modeling System, Version 4.5 for Windows, User's Manual, Environmental Research Software, Hallowell, Maine, 2003.

[30] A.E. Martell, R.M. Smith, NIST Standard Reference Database 46 Version 8.0, NIST Critically Selected Stability Constants of Metal Complexes Database, in: US Department of Commerce, National Institute of Standards and Technology (Eds), 2004.

[31] M.D. Machado, E.V. Soares, Development of a short-term assay based on the evaluation of the plasma membrane integrity of the alga Pseudokirchneriella subcapitata, Appl. Microbiol. Biotechnol. 95 (2012) 1035-1042.

[32] M.D. Machado, E.V. Soares, Optimization of a microplate-based assay to assess esterase activity in the alga Pseudokirchneriella subcapitata, Water Air Soil Pollut. 224 (2013) 1-11.

[33] R.P. Haugland, The Handbook - A Guide to Fluorescent Probes and Labeling Technologies, 10th edition, Invitrogen Corp, Eugene, OR, USA, 2005.

[34] M. Consalvey, R.G. Perkins, D.M. Paterson, G.J.C. Underwood, Pam fluorescence: a beginners guide for benthic diatomists, Diatom Res. 20 (2005) $1-22$.

[35] K. Maxwell, G.N. Johnson, Chlorophyll fluorescence - a practical guide, J. Exp. Bot. 51 (2000) 659-668.

[36] P.B. Fai, A. Grant, B. Reid, Chlorophyll a fluorescence as a biomarker for rapid toxicity assessment, Environ. Toxicol. Chem. 26 (2007) $1520-1531$.

[37] P. Soto, H. Gaete, M.E. Hidalgo, Assessment of catalase activity, lipid peroxidation, chlorophyll-a, and growth rate in the freshwater green algae Pseudokirchneriella subcapitata exposed to copper and zinc, Lat. Am. J. Aquat. Res. 39 (2011) 280-285.

[38] R.J. Ritchie, Universal chlorophyll equations for estimating chlorophylls $a, b, c$, and $d$ and total chlorophylls in natural assemblages of photosynthetic organisms using acetone methanol, or ethanol solvents, Photosynthetica 46 (2008) 115-126.

[39] C.J.F. Ter Braak, Principal components biplots and alpha-diversity and beta-diversity, Ecology 64 (1983) 454-462

[40] A. Ramette, Multivariate analyses in microbial ecology, FEMS Microbiol. Ecol. 62 (2007) 142-160.

[41] C.V.D. Hoek, D.G. Mann, H.M. Jahns, Algae: An Introduction to Phycology, Cambridge University Press, 1995.

[42] L.V. Johnson, M.L. Walsh, L.B. Chen, Localization of mitochondria in living cells with rhodamine 123, Proc. Natl. Acad. Sci. U.S.A. 77 (1980) 990-994.

[43] P. Ludovico, F. Sansonetty, M. Corte-Real, Assessment of mitochondrial membrane potential in yeast cell populations by flow cytometry, Microbiology 147 (2001) 3335-3343.

[44] M.R. Brickley, E. Lawrie, V. Weise, C. Hawes, A.H. Cobb, Use of a potentiometric vital dye to determine the effect of the herbicide bromoxynil octanoate on mitochondrial bioenenergetics in Chlamydomonas reinhardtii Pest Manag. Sci. 68 (2012) 580-586.

[45] E. van der Grinten, M.G. Pikkemaat, E.J. van den Brandhof, G.J. Stroomberg, M.H.S. Kraak, Comparing the sensitivity of algal, cyanobacterial and bacteria bioassays to different groups of antibiotics, Chemosphere 80 (2010) 1-6.

[46] M. Drabkova, H.C.P. Matthijs, W. Admiraal, B. Marsalek, Selective effects of $\mathrm{H}_{2} \mathrm{O}_{2}$ on cyanobacterial photosynthesis, Photosynthetica 45 (2007) 363-369.

[47] E. Pinto, T.C.S. Sigaud-Kutner, M.A.S. Leitao, O.K. Okamoto, D. Morse, P. Colepicolo, Heavy metal-induced oxidative stress in algae, J. Phycol. 39 (2003) 1008-1018.

[48] H.M. Davey, Life, death, and in-between: meanings and methods in microbiology, Appl. Environ. Microbiol. 77 (2011) 5571-5576.

[49] P. Breeuwer, J.L. Drocourt, N. Bunschoten, M.H. Zwietering, F.M. Rombouts, T. Abee, Characterization of uptake and hydrolysis of fluorescein diacetate and carboxyfluorescein diacetate by intracellular esterases in Saccharomyces cerevisiae, which result in accumulation of fluorescent product, Appl. Environ. Microbiol. 61 (1995) 1614-1619.

[50] F.J. Jochem, Probing the physiological state of phytoplankton at the single-cell level, Sci. Mar. 64 (2000) 183-195.

[51] P. Radix, M. Leonard, C. Papantoniou, G. Roman, E. Saouter, S. Gallotti-Schmitt H. Thiebaud, P. Vasseur, Comparison of four chronic toxicity tests using algae, bacteria, and invertebrates assessed with sixteen chemicals, Ecotoxicol. Environ. Saf. 47 (2000) 186-194.

[52] N.M. Franklin, M.S. Adams, J.L. Stauber, R.P. Lim, Development of an improved rapid enzyme inhibition bioassay with marine and freshwater microalgae using flow cytometry, Arch. Environ. Contam. Toxicol. 40 (2001) 469-480. 
[53] M. Jastroch, A.S. Divakaruni, S. Mookerjee, J.R. Treberg, M.D. Brand, Mitochondrial Proton and Electron Leaks, In: Essays in Biochemistry, Portland Press Ltd., London, 2010, pp. 53-67.

[54] S. Kahlert, G. Zundorf, G. Reiser, Detection of de- and hyperpolarization of mitochondria of cultured astrocytes and neurons by the cationic fluorescent dye rhodamine 123, J. Neurosci. Methods 171 (2008) 87-92.

[55] K.T. Nguyen, L.E. Garcia-Chacon, J.N. Barretta, E.F. Barrett, G. David, The Psi(m) depolarization that accompanies mitochondrial Ca2+ uptake is greater in mutant SOD1 than in wild-type mouse motor terminals, Proc. Natl. Acad. Sci. U.S.A. 106 (2009) 2007-2011.

[56] P.X. Petit, Flow cytometric analysis of rhodamine-123 fluorescence during modulation of the membrane-potential in plant-mitochondria, Plant Physiol. 98 (1992) 279-286.

[57] W. Liu, S. Chen, X. Quan, Y.H. Jin, Toxic effect of serial perfluorosulfonic and perfluorocarboxylic acids on the membrane system of a freshwater alga measured by flow cytometry, Environ. Toxicol. Chem. 27 (2008) 1597-1604.
[58] D. Scholz, B. Westermann, Mitochondrial fusion in Chlamydomonas reinhardtii zygotes, Eur. J. Cell Biol. 92 (2013) 80-86.

[59] A. El Berdey, P. Juneau, L. Pirastru, R. Popovic, Application of the PAM fluorometric method for determination of copper toxicity to microalgae and duckweed, in: G. Persoone, C. Janssen, D.C. Wim (Eds.), New Microbiotests for Routine Toxicity Screening and Biomonitoring, Kluwer Academic/Plenum Publishers, New York, 2000, pp. 135-140.

[60] S.Z. Wang, D.Y. Zhang, X.L. Pan, Effects of cadmium on the activities of photosystems of Chlorella pyrenoidosa and the protective role of cyclic electron flow, Chemosphere 93 (2013) 230-237.

[61] Z.T. Horcsik, L. Kovacs, R. Laposi, I. Meszaros, G. Lakatos, G. Garab, Effect of chromium on photosystem 2 in the unicellular green alga Chlorella pyrenoidosa, Photosynthetica 45 (2007) 65-69.

[62] K. Shakya, M.K. Chettri, T. Sawidis, Impact of heavy metals (copper, zinc, and lead) on the chlorophyll content of some mosses, Arch. Environ. Contam. Toxicol. 54 (2008) 412-421. 